\title{
Pendidikan Multikultural Berbantuan Metode Pictorial Riddle Untuk Meningkatkan Karakter Kreatif dan Bersahabat Siswa Kelas 3 Sekolah Dasar
}

\author{
Ika Ari Pratiwi, Siti Masfuah, Wawan Shokib Rondli \\ ika.ari@umk.ac.id, siti.masfuah@umk.ac.id, wawan.shokib@umk.ac.id \\ PGSD Universitas Muria Kudus

\begin{abstract}
Multicultural Education with Pictorial Riddle Method to Improve Student's Creative and Friendly Characters
\end{abstract}

\begin{abstract}
The differences in social, religious, and cultural status make an impact on social attitudes, the cooperative systems, and how to make friends in school. Efforts to harmonize and unify the diversity of students in schools today is integrated with multicultural education. The purpose of this research is to describe the effectiveness of multicultural education implementation with the help of pictorial riddle method to increase the value of creativity, and friendly/communicative character. In this research, the application of multicultural education is carried out in thematic integrated learning of social and natural science in grade 3 semester 2. The quasi experiment design with control group used pre-test and post-test. The result showed that multicultural education, aided with pictorial riddle method increased the value of creative and friendly/communicative character. The creative character in the experimental class increased significantly from the pretest score of 69 to 85 in the posttest, with the gain of 0.53 in the medium criterion. The increase of friendly/communicative value in the pretest experimental class was 70, increased to 80 at posttest, with the gain of 0,31 in medium criterion.
\end{abstract}

Keywords: multicultural education, pictorial riddle method, creative and friendly character

Received date: 23 Oktober 2017

Article Info

Revised date: 1 Maret 2018

Accepted date: 4 Mei 2018

\section{PENDAHULUAN}

Pendidikan merupakan suatu proses kegiatan belajar memperoleh ilmu pengetahuan untuk mengubah perilaku bagi setiap individu. Pendidikan di sekolah diselenggarakan bukan hanya memperoleh pengetahuan namun untuk mejadikan setiap siswa menjadi insan pembelajar yang berbudi pekerti dan mencerminkan karakter bangsa Indonesia. Perlu diketahui bahwa tidak semua siswa di sekolah memiliki latar belakang yang sama. Mereka berasal dari kalangan sosial yang beragam bervariatif, agama dan budaya yang beragam, sehingga memiliki karakter dan kepribadian yang berbeda-beda. Pratiwi, Kanzunnudin, dan Rondli (2016) menyatakan bahwa siswa di beberapa sekolah dasar di Kabupaten Kudus berpadu antara keturunan Jawa dan keturunan Etnis Cina. Adanya perbedaan status sosial, agama, dan budaya tersebut mempengaruhi sikap sosial dan cara berteman di sekolah. Upaya menyelaraskan dan menyatukan keberagaman latar belakang sosial, agama dan budaya pada siswa maka pembelajaran di sekolah saat ini diintegrasikan dengan pendidikan multikultural.

Pendidikan multikultural merupakan sikap memandang keunikan setiap insan manusia dengan tidak membedakan jenis kelamin, budaya, kondisi jasmani maupun status ekonomi seseorang (Skeel, 1995). Ras, suku, agama, budaya dan sosial yang dibawa oleh setiap siswa dapat mempengaruhi setiap tindakan dan perilaku dari diri siswa. Pentingnya pendidikan multikultural diterapkan sejak dini di usia sekolah dasar untuk mengajarkan kepada siswa arti nilai persatuan dalam keberagaman. Guru mengajarkan kepada siswa untuk bersosialisasi 
Pendidikan Multikultural Berbantuan Metode Pictorial Riddle Untuk Meningkatkan Karakter Kreatif dan Bersahabat Siswa Kelas 3 Sekolah Dasar (Ika Ari Pratiwi, Siti Masfuah, Wawan Shokib Rondli)

dengan semua teman tanpa membeda-bedakan, membiasakan kepada siswa untuk bergaul bersama serta menghargai adanya adanya perbedaan dalam keberagaman. Pendidikan multikultural perlu ditanamkan kepada semua siswa di sekolah supaya siswa belajar menghargai, bekerjasama dengan teman yang mempunyai perbedaan latar belakang budaya, agama dan sosial berbeda (Pratiwi, Kanzunnudin dan Rondli: 2016).

Kegiatan pembelajaran di kelas penerapan pendidikan multikultural diintegrasikan pada pelajaran yang sedang diajarkan. Pada penelitian ini penerapan pendidikan multkultural diintegrasikan pada pembelajaran tematik IPA dan IPS kelas 3 SD semester 2. Tujuan penelitian ini adalah mendeskripsikan keefektifan penerapan pendidikan multikultural berbantuan metode pictorial riddle dapat meningkatkan nilai karakter kreatif dan bersahabat/komunikatif. Pada kegiatan penelitian ini siswa diajarkan melakukan kegiatan kelompok bekerjasama dengan anggota lain, pembagian kelompok diarahkan untuk membentuk kelompok bersama teman di bangku belakangnya. Awalnya siswa enggan untuk berkelompok dengan teman yang bukan dengan pilihannnya. Siswa membatasi diri hanya mau bergaul dan bekerjasama dengan teman yang biasa menjadi teman bermain di rumah, terkadang mereka saling mengejek jika merasa tidak cocok saat bergaul. Pada pembelajaran sebelumnya belum memanfaatkan pembelajaran menggunakan media gambar dengan metode pictorial riddle, riddle yang digunakan untuk meningkatkan kreatifitas siswa berupa puzzle berbasis multikultural disusun secara bersama. Siswa belum mempunyai inisiatif sendiri untuk bertanya dan ketika membuat sebuah karya cenderung meniru pekerjaan temannya.

Teknik pembelajaran memanfaatkan gambar untuk menggali pemahaman siswa tentang materi ajar disebut metode picorial riddle. Metode pictorial riddle adalah suatu metode mengembangkan kemampuan berpikir kritis, kreatif dan aktivitas siswa pada kegiatan diskusi kelompok dengan menyajikan masalah kedalam bentuk ilustrasi (Mulyasa, 2011). Media yang digunakan berupa gambar cetak ataupun elektronik yang kemudian dari gambar itu terdapat pertanyaan yang berkaitan dengan riddle tersebut (Hamruni, 2012). Pada penelitian ini digunakan media puzzle berbasis multikultural untuk disusun secara berkelompok menjadi satu gambar yang kemudian sesuai kreatifitas kelompok menjawab pertanyaan berdasarkan gambar dan menjelaskan nilai karakter kreatif dan besahabat yang terkandung pada gambar tersebut. Siswa dituntut bersama kelompoknya mampu menyusun gambar untuk menemukan konsep baru dan menuliskan nilai yang terkandung pada gambar puzzle tersebut.

Wahyuandari dan Rahmawati (2014) menyatakan pendidikan multikultural diharapkan untuk memperkuat perilaku peduli sikap sikap rela untuk memahami dari budaya minoritas. Arifudin (2007) menjelaskan penerapan pendidikan multukultural di sekolah diintegrasikan pada mata pelajaran lainnya, diajarkan kepada siswa mengenai kebersamaan, toleransi, HAM, dan saling menghargai sebagai bekal hidup siswa di kemudian hari dan untuk menegakkan nilai-nilai kemanusiaan. Pada penelitian ini pendidikan multikultural diintegrasikan pada proses pembelajaran bertujuan meningkatkan nilai karakter bangsa, yaitu melatih siswa mampu menerapkan karakter kreatif dan bersahabat/ komunikatif. Hasan, dkk (2010) menjelaskan bahwa nilai karakter kreatif adalah kemampuan berpikir dan melakukan sesuatu yang menghasilkan suatu baru berdasarkan sesuatu yang telah dimiliki. Nilai karakter bersahabat/komunikatif adalah tindakan memperlihatkan rasa senang berbicara, bergaul, dan bekerjasama dengan orang lain. Nilai kreatif dan bersahabat/ komunikatif diterapkan pada siswa sekolah dasar sejak dini agar siswa terbiasa membuat suatu karya dan menyatakan 
perasaan dirinya serta menyadarkan kepada siswa pentingnya hidup bersosialisasi dan melatih mereka mampu berkerjasama dengan siapapun tanpa membedakan latar belakang sosial, budaya, dan agama.

Metode pictorial riddle digunakan sebagai cara untuk melatih siswa mengembangkan kemampuan berpikir kreatif dan melakukan aktivitas secara berkelompok untuk dapat menyusun potongan gambar menjadi satu gambar utuh dengan cepat dan tepat, oleh karena itu dibutuhkan kekompakan dan kerjasama anggota kelompok untuk dapat menyelesaikannya dengan tepat. Kerjasama merupakan salah satu unsur utama yang terkandung pada pembentukan nilai karakter bersahabat dan penanaman pendidikan multikultural bagi siswa untuk saling menerima perbedaan karakter masing-masing anggota sehingga mampu saling menghargai. Siswa kelas 3 SD berada pada taraf berpikir kongkret, untuk mengembangkan kreatifitasnya mereka memerlukan objek nyata atau media untuk mempelajari suatu hal pada kegiatan pembelajaran untuk itu digunakan metode pictorial riddle dengan media gambar puzzle yang disusun secara berkelompok.

\section{KAJIAN PUSTAKA}

\section{Pendidikan Multikultural}

Multikultural adalah cara pandang seseorang tentang ragam kehidupan di dunia, ataupun kebijakan kebudayaan yang menekankan pada penerimaan realitas keragaman, dan berbagai macam budaya (multikultural) yang ada dalam kehidupan masyarakat menyangkut nilai-nilai, sistem, budaya, kebiasaan, dan kepercayaan yang mereka anut (Suryana dan Rusdiana, 2015). Multikulturalisme merupakan ideologi yang menjadikan wahana untuk meningkatkan derajat manusia, mengakui dan mengakui perbedaan dalam kesederajatan baik secara individual maupun secara kebudayaan (Ibrahim: 2013). Skeel (1995) menjelaskan pendidikan multikultural yaitu suatu sikap untuk memandang keunikan pada setiap individu seseorang dengan tidak membedakan budaya, ras, kondisi jasmaniah, jenis kelamin, ataupun status ekonomi setiap orang. Liliweri (2005) menguraikan bahwa pendidikan multikultural yaitu strategi pendidikan dengan memanfaatkan keberagaman latar belakang kebudayaan dari setiap siswa sebagai unsur kekuatan dalam membentuk sikap sosial. Fatmawati, dkk (2018) mengemukakan pendidikan multikulturalisme mengajarkan tentang menghargai semua peserta didik tanpa mendang latar belakang, jenis kelamin, kelas sosial, etnis, ras, agama, dan budayanya. Semua peserta didik memiliki kesempatan yang sama untuk belajar di sekolah. Berdasarkan beberapa pendapat ahli dapat disimpulkan bahwa pendidikan multikultural adalah kegiatan pembelajaran untuk membentuk sikap sosial siswa dengan memanfaatkan keberagaman dalam pergaulan tanpa memandang perbedaan budaya, ras, kondisi jasmaniah, jenis kelamin maupun status sosial masing-masing siswa.

Tujuan pendidikan dengan berbasis multikultural menurut Skeel (1995) yaitu: 1) membantu siswa membangun perilaku positif adanya perbedaan ras, etnik, budaya dan agama; 2) membantu siswa membangun kerjasama lintas budaya serta memberikan pandangan positif mereka mengenai keragaman; 3) melatih ketahanan siswa dengan mengajarkan mereka cara mengambil keputusan dan keterampilan sosial dalam pergaulan; 4) mewadahi sekolah untuk berperan memfasilitasi siswa yang beranekaragam. Zamroni (2011) menjelaskan tujuan pendidikan multikultural yang dikembangkan pada diri siswa antara lain: 1) mempunyai kemampuan berpikir kritis tentang hal yang telah dipelajari; 2) memiliki kesadaran atas sifat prasangka terhadap orang lain sehingga mampu mengkaji mengapa sifat itu muncul serta terus mengkaji bagaimana cara menghilangkannya; 3) memahami bahwa setiap ilmu pengetahuan dapat dipergunakan untuk meningkatkan keadilan sosial; 4) dapat mengaplikasikan ilmu pengetahuan yang dimiliki dalam kehidupan; 5) memahami hubungan kejadian yang dilakukan dengan berbagai masalah dalam kehidupan sehari-hari. 
Pendidikan Multikultural Berbantuan Metode Pictorial Riddle Untuk Meningkatkan Karakter Kreatif dan Bersahabat Siswa Kelas 3 Sekolah Dasar (Ika Ari Pratiwi, Siti Masfuah, Wawan Shokib Rondli)

\section{Metode Pictorial Riddle}

Pictorial riddle berasal dari kata pictorial yang berarti gambar dan riddle yang berarti tebakan. Purwanto dan Hasanah (2014) menjelaskan pictorial riddle adalah metode pembelajaran untuk mengembangkan aktivitas siswa dalam diskusi kelompok kecil maupun besar melalui penyajian masalah yang disajikan dalam bentuk ilustrasi gambar. Berkaitan dengan metode tersebut, Hamruni (2012) menjelaskan pictorial riddle adalah salah satu metode yang dapat mengembangkan motivasi dan keterkaitan siswa di dalam diskusi kelompok kecil ataupun besar.

Pictorial riddle digunakan untuk menyampaikan informasi ilmiah dalam bentuk gambar yang digunakan sebagai sumber diskusi. Langkah yang harus diikuti guru dalam membuat desain suatu riddle yaitu: a) memilih konsep yang akan disampaikan atau didiskusikan; b) melukiskan suatu gambar, menunjukkan ilustrasi yang menunjukkan konsep, proses, atau situasi; c) membuat pertanyaan yang berorientasi proses dan berkaitan dengan riddle (gambar dan sebagainya) untuk membantu siswa memperoleh konsep yang terlibat di dalamnya. Kelebihan metode pictorial riddle yaitu merangsang siswa dapat mengeluarkan ide kreatifnya terhadap pemasalahan dalam bentuk teka-teki bergambar. Sedangkan kelemahannya adalah sulit mengkondisikan kelas dikarenakan oleh aktivitas belajar kelompok dan tekadang belum berani untuk menyampaikan idenya.

\section{Karakter Kreatif}

Setiap manusia pasti memiliki kesadaran untuk melakukan suatu hal membuat suatu hasil karya dan menuangkan perasaan dirinya dalam bentuk gambar, seni dan komunikasi. Hasan (2010) menjelaskan kreatif adalah kemampuan siswa dalam berpikir dan melakukan sesuatu yang menghasilkan cara atau hasil baru berdasarkan sesuatu yang dimiliki. Wahyuni dan Mustadi (2016) berpendapat bahwa kreatif merupakan kapasitas seseorang untuk menghasilkan ide-ide baru yang asli, menjadi ilmiah, berwawasan, bernilai estetika, mempunyai nilai sosial dan nilai teknologi.

Indikator nilai karakter kreatif bagi siswa sekolah dasar kelas rendah (1-3) menurut Hasan (2010) termuat pada Tabel 1 berikut.

Tabel 1.

Penerapan Nilai Karakter Kreatif

\begin{tabular}{ll}
\hline \multicolumn{1}{c}{ INDIKATOR } & \multicolumn{1}{c}{ KOMPONEN } \\
\hline $\begin{array}{l}\text { membuat karya dari bahan yang } \\
\text { tersedia di kelas }\end{array}$ & $\begin{array}{l}\text { membuat puzzle dari bahan yang ada di } \\
\text { kelas }\end{array}$ \\
\hline $\begin{array}{l}\text { mengusulkan suatu kegiatan baru di } \\
\text { kelas }\end{array}$ & perlombaan menyusun puzzle \\
\hline $\begin{array}{l}\text { menyatakan persaannya dalam gambar, } \\
\text { seni bentuk komunikasi lisan dan tulis }\end{array}$ & $\begin{array}{l}\text { merangkai puzzle menjadi suatu gambar } \\
\text { yang utuh }\end{array}$ \\
\hline $\begin{array}{l}\text { melakukan tindakan untuk membuat } \\
\text { kelas menjadi nyaman }\end{array}$ & $\begin{array}{l}\text { melakukan diskusi kelompok dengan } \\
\text { tertib }\end{array}$ \\
\cline { 2 - 2 } & $\begin{array}{l}\text { Melakukan permainan bersama anggota } \\
\text { kelompok }\end{array}$ \\
\hline
\end{tabular}

\section{Karakter bersahabat}

Hasan (2010) menjelaskan karakter bersahabat adalah tindakan memperlihatkan perasaan senang bergaul, berbicara dan bekerjasama dengan orang lain. Perilaku untuk menanamkan rasa bersahabat antara lain: berbicara dengan bahasa dengan santun, saling menghargai dan menjaga kehormatan, serta saat berkomunikasi guru tidak menjaga jarak dengan siswa (Pratiwi, 2016). Perilaku bersahabat/ komunikatif berdasarkan hasil penelitian Zainuddin (2013) yaitu: siswa berupaya saling bekerjasama, menjalin komunikasi pada 
anggota kelompoknya, siswa mampu menghargai guru dan mau melaksanakan langkah model pembelajaran kooperatif yang dipersiapkan guru.

Indikator nilai bersahabat/ komunikatif bagi siswa sekolah dasar kelas rendah (1-3) disebutkan oleh Hasan (2010) penelitian termuat pada Tabel 2 berikut.

Tabel 2.

Penerapan Nilai Karakter Bersahabat dan Komunikatif

\begin{tabular}{|c|c|}
\hline INDIKATOR & KOMPONEN \\
\hline \multirow{2}{*}{$\begin{array}{l}\text { Bekerjasama dalam kelompok } \\
\text { di kelas }\end{array}$} & Siswa mau berkelompok dengan teman tanpa memiilih-milih \\
\hline & Siswa dapat bekerjasama dalam kelompok tanpa paksaan dari guru \\
\hline \multirow{4}{*}{$\begin{array}{l}\text { Berbicara dengan teman di } \\
\text { kelas }\end{array}$} & Siswa tidak mendiamkan teman yang sedang berbicara kepadanya \\
\hline & Siswa berbicara dengan teman saat bekerja kelompok \\
\hline & Siswa memperhatikan pembicaraan saat kegiatan diskusi \\
\hline & $\begin{array}{l}\text { Siswa berbicara dengan baik kepada teman (tidak membentak- } \\
\text { bentak) }\end{array}$ \\
\hline \multirow{4}{*}{$\begin{array}{l}\text { Bergaul dengan teman sekelas } \\
\text { ketika istirahat }\end{array}$} & Siswa tidak diam sendiri/ tinggal di kelas pada waktu istirahat \\
\hline & $\begin{array}{l}\text { Siswa dapat berbicara tanpa mengejek temannya pada saat } \\
\text { istirahat }\end{array}$ \\
\hline & Siswa dapat bergaul dengan baik tanpa memusuhi teman \\
\hline & $\begin{array}{l}\text { Siswa mampu bermain bersama teman dengan baik tanpa memiilih- } \\
\text { milih }\end{array}$ \\
\hline \multirow{3}{*}{$\begin{array}{l}\text { Bergaul dengan teman lain } \\
\text { kelas }\end{array}$} & Siswa mau mengenal adik kelas dan kakak kelas di sekolahnya \\
\hline & Siswa mau menyapa adik kelas dan kakak kelasnya \\
\hline & $\begin{array}{l}\text { Siswa dapat bermain bersama adik kelas atau kakak kelas saat } \\
\text { istirahat }\end{array}$ \\
\hline \multirow[t]{3}{*}{ Berbicara dengan guru } & $\begin{array}{l}\text { Siswa mau menyapa dan memberi salam jika bertemu dengan } \\
\text { bapak/ibu guru }\end{array}$ \\
\hline & Siswa dapat menjabat tangan ketika bertemu dengan bapak/ibu guru \\
\hline & Siswa mampu berbicara dengan sopan kepada bapak/ibu guru \\
\hline
\end{tabular}

Penelitian ini sejalan dengan hasil penelitian oleh Fatmawati, dkk (2018) bahwa hasil pengembangan modul pendidikan multikultural berbasis karakter cinta tanah air dan nasionalisme pada pembelajaran tematik bertujuan untuk mendeskripsikan langkah-langkah pengembangan modul pendidikan multukultural sebagai acuan untuk mengembangkan modul yang sesuai dengan kebutuhan siswa. Pratiwi (2016) mengemukakan hasil penelitian bahwa pendidikan multikultural sebagai sarana untuk menanamkan nilai karakter di sekolah dasar. Masfuah (2016) menjelaskan bahwa hasil penelitiannya menggunakan metode pictorial riddle dapat meningkatkan keterampilan berpikir kritis dan motivasi berprestasi siswa.

\section{METODE PENELITIAN}

Penelitian pendidikan multikultural bermetode pictorial riddle untuk meningkatkan karakter kreatif dan bersahabat/komunikatif menggunakan desain penelitian kuasi eksperimen dengan rancangan control group pre-test post-test (Arikunto, 2006: 86), dengan objek penelitian SD 1 Gondangmanis sebagai kelompok eksperimen dan SD 4 Gondangmanis sebagai kelompok kontrol. Instrumen penelitian ini berupa lembar observasi, lembar wawancara, LKS dan soal tes. Karakter kreatif diukur menggunakan instrumen tes dan lembar observasi, sedangkan karakter bersahabat diukur dengan instrumen lembar observasi.

Analisis data terdiri atas analisis data tahap awal dan analisis data tahap akhir. Analisis data tahap awal yaitu: (1) analisis validitas bahan ajar yang digunakan untuk menilai seberapa valid dan layak menggunakan instrumen observasi untuk mengukur nilai karakter kreatif dan bersahabat/komunikatif; (2) uji homogenitas menentukan kelas eksperimen dan 
Pendidikan Multikultural Berbantuan Metode Pictorial Riddle Untuk Meningkatkan Karakter Kreatif dan Bersahabat Siswa Kelas 3 Sekolah Dasar (Ika Ari Pratiwi, Siti Masfuah, Wawan Shokib Rondli)

kelas kontrol dalam uji coba skala luas. Tahap berikutnya adalah analisis tahap akhir yang meliputi: 1) uji normalitas, 2) uji tes yang diitegrasikan dengan pendidikan multikultural, 3) uji hipotesis penelitian dengan t-test perbedaan dua rata-rata (Sugiyono, 2009) dan uji gain (Hake, 1998) untuk mengetahui peningkatannya.

\section{HASIL DAN PEMBAHASAN}

\section{Hasil Penelitian}

Berdasarkan langkah penelitian dan pengembangan (R\&D) dari Sugiyono (2009) penelitian yang dilakukan memperoleh data analisis sebagai berikut

\section{Analisis Data Tahap Awal}

Analisis data tahap awal bertujuan untuk mengetahui keadaan awal siswa. Data yang digunakan dalam analisis data tahap awal yaitu data hasil pretest. Hasil pretest ini digunakan untuk mengukur karakter kreatif siswa. Karakter kreatif siswa diukur dengan instrumen tes dan lembar observasi. Analisis data tahap awal ini dimulai dengan uji normalitas dan uji kesamaan dua varian. Hasil analisis data tahap awal dapat dilihat pada Tabel 3.

Tabel 3.

Hasil Analisis Data Prates Tahap Awal

\begin{tabular}{cccc}
\hline Pengujian & Sumber variasi & Kelas Kontrol & Nilai Pretest \\
\hline $\begin{array}{c}\text { Uji kesamaan } \\
\text { dua varians }\end{array}$ & F hitung & & 1,42 \\
& F table & 2,74 \\
& Kriteria & kedua kelompok mempunyai varians yang sama \\
\hline
\end{tabular}

Berdasarkan pada Tabel 1 kedua kelompok mempunyai varians yang sama baik untuk kelas kontrol mapun kelas eksperimen, sehingga dapat dilakukan penghitungan analisis parametrik.

\section{Analisis Data Tahap Akhir}

Analisis data tahap akhir dilakukan penghitungan uji normalitas dan uji homogenitas, uji perbedaan dua rata-rata dan uji gain karakter kreatif dan bersahabat/komunikatif. Data akhir diperoleh dari nilai postest. Postest bertujuan untuk mengukur peningkatan karakter kreatif dan bersahabat/komunikatif siswa. Rekapitulasi hasil uji normalitas dan uji homogenitas dapat dilihat pada Tabel 4.

Tabel 4.

Hasil Uji Normalitas dan Uji Homogenitas

\begin{tabular}{|c|c|c|c|c|c|}
\hline $\mathbf{U j i}$ & $\begin{array}{l}\text { Sumber } \\
\text { Variasi }\end{array}$ & $\begin{array}{c}\text { Postes } \\
\text { karakter } \\
\text { kreatif } \\
\text { Kelas Kontrol }\end{array}$ & $\begin{array}{c}\text { Postes karakter } \\
\text { kreatif } \\
\text { Kelas } \\
\text { Eksperimen }\end{array}$ & $\begin{array}{c}\text { Postes } \\
\text { karakter } \\
\text { bersahabat } \\
\text { Kelas Kontrol }\end{array}$ & $\begin{array}{c}\text { Postes kerkter } \\
\text { bersahabat } \\
\text { Kelas } \\
\text { Eksperimen } \\
\end{array}$ \\
\hline \multirow[t]{3}{*}{ Normalitas } & $X_{\text {hitung }}^{2}$ & 2,14 & 3,73 & 76 & 80 \\
\hline & $X_{\text {tabel }}^{2}$ & 9,49 & 9,49 & 9,49 & 9,49 \\
\hline & Kriteria & $\begin{array}{c}\text { Data } \\
\text { berdistribusi } \\
\text { normal }\end{array}$ & $\begin{array}{c}\text { Data } \\
\text { berdistribusi } \\
\text { normal }\end{array}$ & $\begin{array}{c}\text { Data } \\
\text { berdistribusi } \\
\text { normal }\end{array}$ & $\begin{array}{c}\text { Data } \\
\text { berdistribusi } \\
\text { normal }\end{array}$ \\
\hline \multirow[t]{2}{*}{ Homogenitas } & F hitung & 1,2 & Kedua kelas & 1,24 & Kedua kelas \\
\hline & F tabel & 2,74 & homogeny & 2,74 & homogen \\
\hline
\end{tabular}

Berdasarkan Tabel 2, kedua kelas normal dan homogen sehingga dapat dilakukan uji statistik parametris. Uji hipotesis ini digunakan uji perbedaan dua rata-rata. Rekapitulasi uji hipotesis dengan uji perbedaan dua rata-rata dapat dilihat pada Tabel 5. 
Tabel 5.

Hasil Uji Perbedaan Dua Rata-rata Postest

\begin{tabular}{|c|c|c|c|c|}
\hline \multirow{2}{*}{ Variasi } & \multicolumn{2}{|c|}{ Nilai Postest Karakter Kreatif } & \multicolumn{2}{|c|}{ Nilai postest Karakter Bersahabat } \\
\hline & Kelas kontrol & Kelas eksperimen & Kelas kontrol & Kelas eksperimen \\
\hline Rata-rata & 77 & 85 & 76 & 80 \\
\hline $\mathrm{dk}$ & 36 & 36 & 36 & 36 \\
\hline$t_{\text {hitung }}$ & \multicolumn{2}{|c|}{2,257} & \multicolumn{2}{|r|}{2,06} \\
\hline$t_{\text {tabel }}$ & \multicolumn{2}{|c|}{2,03} & \multicolumn{2}{|c|}{2,03} \\
\hline Kriteria & \multicolumn{2}{|c|}{$\begin{array}{c}\text { Kemampuan karakter kreatif kelas eksperimen } \\
\text { lebih baik daripada kelas kontrol }\end{array}$} & \multicolumn{2}{|c|}{$\begin{array}{l}\text { Nilai karakter bersahabat siswa kelas } \\
\text { eksperimen sama dengan nilai karakter } \\
\text { siswa kelas kontrol }\end{array}$} \\
\hline
\end{tabular}

Berdasarkan Tabel 5 hasil uji perbedaan dua rata-rata nilai postest karakter kreatif pada kelas kontrol rata-rata nilai 77 sedangkan kelas eksperimen 85, hasil analisis $t_{\text {hitung }}>t_{\text {tabel }}$ yaitu 2,257 > 2,03, maka kriteria nilai karakter kreatif kelas eksperimen lebih baik daripada kelas kontrol. Nilai postest karakter bersahabat/ komunikatif pada kelas kontrol rata-rata nilai 76 sedangkan kelas eksperimen 80 , hasil analisis $t_{\text {hitung }}>t_{\text {tabel yaitu }} 2,06>2,03$ maka kriteria nilai karakter bersahabat siswa kelas eksperimen sama dengan nilai karakter siswa kelas kontrol. Rekapitulasi uji gain pada kemampuan berpikir kreatif dapat dilihat pada Tabel 6.

Tabel 6.

Hasil Uji Gain Karakter Kreatif

\begin{tabular}{|c|c|c|c|c|}
\hline Rata-rata & Pretes & Postes & Gain & Kriteria \\
\hline Eksperimen & 69 & 85 & 0,53 & sedang \\
\hline Kontrol & 69 & 77 & 0,25 & rendah \\
\hline
\end{tabular}

Hasil peningkatan nilai karakter kreatif pada kelas eksperimen memperoleh skor gain 0,53 kriteria sedang dengan nilai pretes 69 meningkat pada postest menjadi 85. Sedangkan pada kelas kontrol memperoleh skor gain 0,25 kriteria rendah dengan nilai pretes 69 meningkat pada postest menjadi 77. Peningkatan (gain) nilai karakter kreatif siswa dapat dilihat pada Gambar 1.

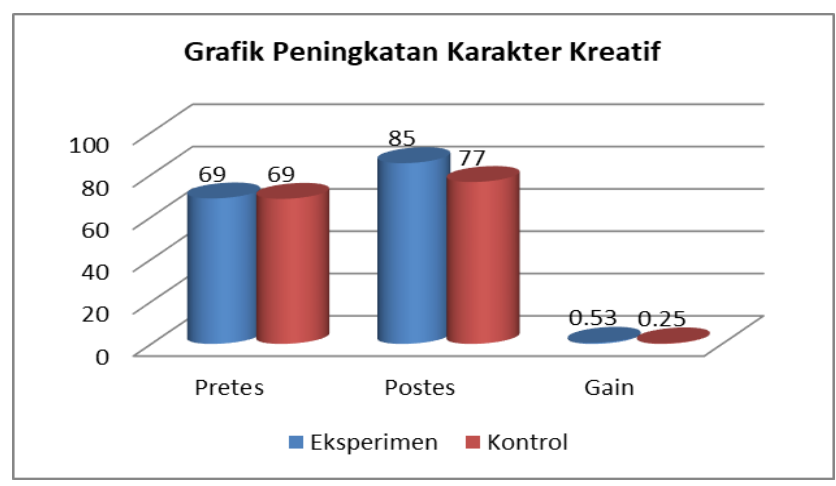

Gambar 1.

Grafik Peningkatan Nilai Karakter Kreatif

Rekapitulasi uji gain pada karakter bersahabat/komunikatif dapat dilihat pada Tabel 7.

Tabel 7.

Hasil Uji Gain Karakter Bersahabat/ Komunikatif

\begin{tabular}{|c|c|c|c|c|}
\hline Rata-rata & Pretes & Postes & Gain & Kriteria \\
\hline Eksperimen & 70 & 80 & 0,31 & sedang \\
\hline Kontrol & 70 & 76 & 0,21 & rendah \\
\hline
\end{tabular}


Hasil peningkatan karakter bersahabat/komunikatif pada kelas eksperimen memperoleh skor gain 0,31 kriteria sedang dengan nilai pretes 70 meningkat pada postest menjadi 80 . Sedangkan pada kelas kontrol memperoleh skor gain 0,21 kriteria rendah dengan nilai pretes 70 meningkat pada postest menjadi 76. Peningkatan (gain) karakter bersahabat/komunikatif dapat dilihat pada Gambar 2.

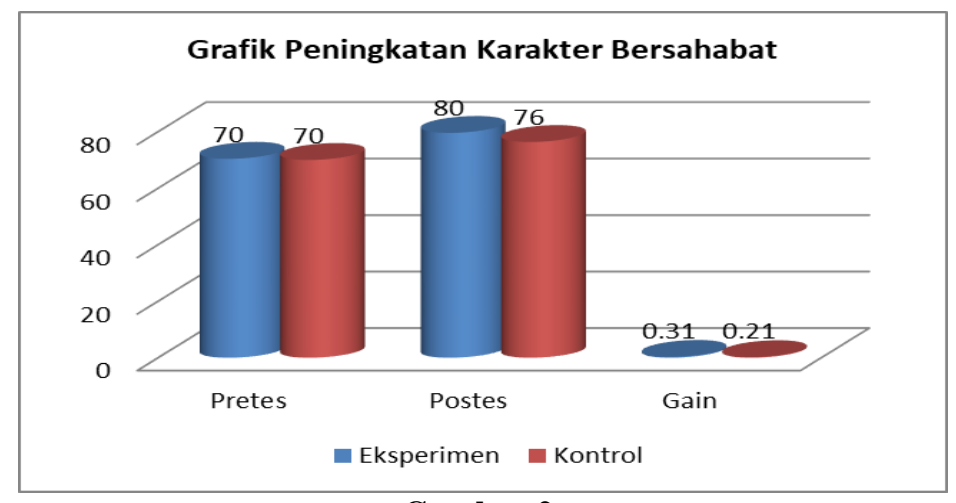

Gambar 2.

Grafik Peningkatan Karakter Bersahabat/ Komunikatif

\section{Pembahasan}

Hasil penelitian pendidikan multikultural berbantuan metode pictorial riddle mampu meningkatkan karakter kreatif dan bersahabat. Penelitian dilaksanakan pada pembelajaran tematik kelas 3 SD pada pelajaran IPA dan IPS. Produk yang dikembangkan adalah bahan ajar siswa berupa modul pendidikan multikultural bermuatan nilai karakter kreatif dan bersahabat/ komunikatif. Bahan ajar yang dikembangkan di validasi oleh ahli sesuai dengan bidangnya, sudah direvisi sehingga sudah layak untuk digunakan pada pembejalaran. Pendidikan multikultural yang diterapkan pada pembelajaran di kemas dalam modul. Aplikasi pendidikan multikultural bermuatan nilai karakter kreatif dan bersahabat/ komunikatif dilaksanakan pada Lembar Kerja Siswa (LKS), kegiatan pengamatan dan kegiatan kerja kelompok sesuai dengan petunjuk kegiatan yang ada pada modul tersebut. Pada kegiatan ini siswa dilatih melakukan kegiatan secara berkelompok tanpa memiilihmilih, diajak memberikan kontribusi melakukan kegiatan yang menarik belajar sambil bermain, siswa dapat melakukan kegiatan pembelajaran dengan senang dan antusias, pada akhirnya siswa dapat memaknai keberagaman dalam pergaulan sebagai suatu sarana untuk menumbuhkan persatuan. Hal tersebut sepaham dengan pendapat Pratiwi, Kanzunnudin, dan Rondli (2016) bahwa guru sangat berperan dalam proses pembelajaran untuk mengajarkan dan memberi nilai yang bermakna memandang status sosial, latar belakang dan budaya siswa.

Metode pictorial riddle ini diterapkan dengan menggunakan media puzzle yang disusun menjadi gambar kartun bermuatan nilai karakter dan gambar kegiatan keberagaman di sekolah yang menunjukkan multikultural. Pictorial riddle ini digunakan untuk mengembangkan motivasi dan kreatif siswa dengan menyusun puzzle menjadi suatu gambar yang utuh. Penggunaan media gambar puzzle pada kegiatan pembelajaran lebih memberi pemahaman pada siswa tentang materi yang disampaikan dalam hal ini adalah untuk mempelajari materi IPA dan IPS. Siswa dapat menjelaskan gambar puzzle yang telah tersusun dan memberikan pendapat yang berkaitan dengan pendidikan multikultural dan pendidikan karakter.

Berdasarkan penelitian yang telah dilaksaksanakan, maka didapatkan hasil bahwa pendidikan multikultural berbantuan metode pictorial riddle dapat meningkatkan nilai karakter kreatif dan bersahabat/ komunikatif. Berdasarkan hasil penelitian peningkatan nilai 
karakter kreatif pada kelas eksperimen meningkat secara signifikan dari skor pretes 69 meningkat pada postest menjadi 85, uji gain skor 0,53 dengan kriteria sedang. Hasil penelitian ini terlihat adanya peningkatan pada indikator nilai kreatif yaitu: menyusun suatu karya dari alat dan bahan yang ada di kelas meskipun belum maksimal karena proses pembuatannya dibantu oleh guru, siswa dapat mengusulkan untuk mengadakan perlombaan menyusun puzzle antar kelompok di kelas, siswa dapat merangkai puzzle menjadi suatu gambar yang utuh dan menjelaskan unsur multikultural, serta mampu melakukan hal yang nyaman dalam kegiatan berkelompok meskipun dari latar belakang ekonomi, sosial dan agama yang berbeda-beda.

Hasil penelitian pendidikan multikultural pada peningkatan nilai bersahabat/ komunikatif pada kelas eskperimen hasil pretest adalah 70 meningkat menjadi 80 pada postest, uji gain dengan skor 0,31 dengan kriteria sedang. Berdasarkan hasil nilai karakter bersahabat aspek yang meningkat adalah siswa mau bekerjasama dengan kelompok tanpa paksaan, berbicara dengan teman saat kerja kelompok dan dapat membantu teman yang kesulitan saat menyusun puzzle. Ketika bergaul dengan teman sekelas saat istirahat mereka tampak rukun, bermain dan bercanda bersama serta saling berbagi bekal makanan. Hal ini sesuai dengan penjelasan Zainuddin (2003) bahwa indikasi brsahabat/ komunikatif adalah saling memberi bantuan teman yang membutuhkan dan menolong teman yang meminta bantuan. Siswa dapat berperilaku hormat kepada guru yaitu berbicara sopan kepada guru, saat bertemu dengan guru siswa menyapa dan berjabat tangan. Namun ada aspek yang belum meningkat dengan maksimal yaitu bergaul dengan teman lain kelas, hal ini disebabkan karena mereka merasa canggung bergaul dengan teman tidak seumuran dan tidak terbiasa berkomunikasi sehingga kurang akrab dengan siswa dari kelas lain.

Aplikasi pendidikan multikultural yang terintegrasi dalam proses pembelajaran adalah mampu membentuk siswa yang berkepribadian, peduli sosial, serta cinta tanah air sehingga menjadi seorang siswa yang berkarakter bangsa (Pratiwi, 2016). Hal ini terbukti pada kegiatan penelitian yang telah dilakukan menggunakan bantuan pictorial riddle siswa dapat memaknai keberagaman untuk mewujudkan kebersamaan, siswa dapat menanamkan nilai karakter kreatif dan bersahabat melalui kegiatan pembelajaran dengan melaksanakan aspekaspek nilai karakter yang telah dikembangkan oleh peneliti. Adanya beberapa latar belakang sosial, ekonomi dan agama harus ditanamkan kepada siswa sebagai alat pemersatu untuk tetap menjadi kerukunan sehingga pada akhirnya siswa memiliki wawasan dan pandangan bahwa multikultural di Indonesia merupakan anugerah Tuhan Yang Maha Esa yang harus tetap dijaga keutuhannya.

\section{SIMPULAN}

Pendidikan di sekolah diselenggarakan bukan hanya memperoleh pengetahuan namun untuk mejadikan setiap siswa menjadi insan pembelajar yang berbudi pekerti dan mencerminkan karakter bangsa Indonesia. Perbedaan status sosial, agama dan budaya tersebut menjadikan pengaruh terhadap sikap sosial, sistem bekerjasama dan cara berteman siswa di sekolah. Upaya menyelaraskan dan menyatukan keberagaman latar belakang sosial, agama dan budaya pada siswa maka pembelajaran di sekolah saat ini diintegrasikan dengan pendidikan multikultural. Pada penelitian ini penerapan pendidikan multkultural diintegrasikan pada pembelajaran tematik IPA dan IPS kelas 3 SD semester 2. Tujuan penelitian ini adalah mendeskripsikan keefektifan penerapan pendidikan multikultural berbantuan metode pictorial riddle untuk meningkatkan nilai karakter kreatif dan bersahabat/ komunikatif.

Penelitian pendidikan multikultural berbantuan pictorial riddle untuk meningkatkan karakter kreatif dan bersahabat/ komunikatif menggunakan prosedur penelitian Research and Development $(R \& D)$ yang diadaptasi dari Sugiyono (2009). Penelitian yang telah dilakukan 
Pendidikan Multikultural Berbantuan Metode Pictorial Riddle Untuk Meningkatkan Karakter Kreatif dan Bersahabat Siswa Kelas 3 Sekolah Dasar (Ika Ari Pratiwi, Siti Masfuah, Wawan Shokib Rondli)

memperoleh hasil bahwa pendidikan multikultural berbantuan metode pictorial riddle dapat meningkatkan nilai karakter kreatif dan bersahabat/ komunikatif. Peningkatan nilai karakter kreatif pada kelas eksperimen meningkat secara signifikan dari skor prates 69 meningkat pada postest menjadi 85, uji gain skor 0,53 dengan kriteria sedang. peningkatan nilai bersahabat/komunikatif pada kelas eskperimen hasil pratest adalah 70 meningkat menjadi 80 pada postest, uji gain dengan skor 0,31 dengan kriteria sedang.

\section{DAFTAR PUSTAKA}

Arifudin, I. 2007. Urgensi Implementasi Pendidikan Multkultural di Sekolah. Jurnal Pemikiran Alternatif Pendidikan (1) (2): 1-9

Ardianti, Pratiwi dan Kanzunnudin. 2017. Implementasi PjBL Berpendekatan Science Edutainment Terhadap Kreatifitas Peserta Didik. Jurnal Refleksi Edukatika (7) (2): $145-150$

Fatmawati, L., Pratiwi, R. D., \& Erviana, V. Y. (2018). Pengembangan Modul Pendidikan Multikultural Berbasis Karakter Cinta Tanah Air dan Nasionalis pada Pembelajaran Tematik. Scholaria: Jurnal Pendidikan dan Kebudayaan, 8(1), 8092.

Hake. R. 1998. Interactive-Engagement Versus Traditional Methods: A Six-thousand-student survey of Mechanics Test Data For Introductory Physics Course. American Association of Physics Teacher. 66 (1):64

Hamruni. 2012. Strategi dan Model-model Pembelajaran Aktif-Menyenagkan. Yogyakarta: Investidaya

Hasan, dkk. 2010. Pengembangan Pendidikan Budaya dan Karakter Bangsa. Jakarta: Balitbang

Ibrahim. 2013. Pendidikan Multikultural: Pengertian, Prinsip, dan Relevansinya dengan Tujuan Pendidikan Islam. Jurnal ADDIN (7) (1): 129-154

Liliweri,A. 2005. Prasangka \& Konflik: Komunikasi Lintas Budaya Masyarakat Multikultural. Yogyakarya: LKiS

Masfuah. 2016. Pembelajaran Attention, Relevance, Confidence, Satisfaction (ARCS) dengan metode pictorial riddle untuk meningkatkan keterampilan berpikir kritis dan motivasi berprestasi siswa. Jurnal Refleksi Edukatika (6) (2)

Mulyasa. 2011. Menjadi Guru Profesional. Bandung: Remaja Rosdakarya

Pratiwi. 2016. Pendidikan Multikutural untuk Menanamkan Karakter Bangsa Bagi Siswa Sekolah Dasar. Prosiding Seminar Nasional 1st TELCECON. Kudus: Badan Penerbit UMK

Pratiwi, Kanzunnudin dan Rondli. 2016. Penerapan Model Jigsaw untuk Meningkatkan Hasil Belajar IPS Berbasis Multikultural. Jurnal Konseling Gusjigang. (2) (1): 111-119

Purwanto dan Hasanah. 2014. Efektivitas Model Pembelajaran Inkuiri Tipe Pictorial Riddle dengan Konten Integrasi-Interkoneksi Pada Materi Suhu dan Kalor Terhadap Kemampuan Berfikir Siswa. Jurnal Kaunia (10) (2): 117 - 127

Skeel, D.J. 1995. Elementary Social Studies: Challenge for Tomarrow"s World. New York: Harcourt Brace College Publishers.

Sugiyono. 2009. Penelitian Kualitatif, Kuantitatif dan R \& D. Bandung: ALFABETA 
Suryana dan Rusdiana. 2015. Pendidikan Multikultural Suatu Upaya Penguatan Jati Diri Bangsa Konsep-Prinsip-Implementasi. Bandung: Pustaka Setia

Wahyuandari,W dan Rahmawati, D. 2014. Pendidikan Multikultural (Studi Kasus di Sekolah Lanjutan Tingkat Pertama di Tulungagung). Jurnal Universitas Tulungagung BONOROWO (2) (1)

Wahyuni dan Mustadi. 2016. Pengembangan Perangkat Pembelajaran Collaborative Learning Berbasis Kearifan Lokal untuk Meningkatkan Karakter Kreatif dan Bersahabat. Jurnal Pendidikan Karakter (VI) (2): 246-260

Zainuddin. 2013. Implementasi Pembentukan Karakter Bersahabat Melalui Model Pembelajaran Group Investigasi. Mimbar. (29) (1): 69-76

Zamroni. 2011. Pendidikan Demokrasi Pada Masyarakat Multikultural. Yogyakarta: Gavin Kalam Utama 